\title{
Forum
}

PMLA invites members of the association to submit letters, printed and double-spaced, that comment on articles in previous issues or on matters of general scholarly or critical interest. The editor reserves the right to reject or edit Forum contributions and offers the PMLA authors discussed in published letters an opportunity to reply. The journal omits titles before persons' names, discourages footnotes, and does not consider any letter of more than one thousand words. Letters should be addressed to PMLA Forum, Modern Language Association, 26 Broadway, 3rd floor, New York, NY 10004-1789.

\section{Submissions to a Changed Journal}

\section{TO THE EDITOR:}

I was interested to follow the discussion in your Forum pages of why PMLA submissions have dropped in recent years (116 [2001]: 650-56). As an erstwhile contributor, specialist reader on many occasions, and former member of the Advisory Committee (1986-90), I've seen both sides of the process. For many years I thought PMLA was certainly the best journal to submit essays to, not only because they would, if accepted, find more readers there but also because the comments they would receive from specialist readers, even if they were rejected, would probably be fuller and more helpful than those they would receive anywhere else. If an article was accepted, the editorial staff at PMLA would do a superb job of suggesting minor but significant revisions to improve its clarity, energy, and persuasiveness. No other article I ever published was treated with the intelligence, tact, and good sense given to the two I published there.

Between the two, however, my momentum was slowed by a speed bump. Another essay I submitted was praised and strongly recommended for publication by both its readers and then summarily rejected by the Editorial Board without any reason given: "an excellent essay," the executive director wrote, "but one which, in the opinion of the Board, is not of such significance as to justify bringing it to the attention of PMLA's 30,000 readers." Maybe so, but I guessed that my views had clashed with those of the board member who was a specialist in the field.

Grateful for the treatment accorded my two successful articles (they both won the William Riley Parker Prize), I tried to offer the same careful criticism mine had received when I was invited to screen other essays as a specialist reader and later as a member of the Advisory Committee. But for many years I submitted no more pieces to PMLA,

(C) 2002 BY THE MODERN LANGUAGE ASSOCIATION OF AMERICA 
partly because, as Patrick O'Donnell and others suggest, a lot of what I was writing had already been asked for or promised elsewhere, or was a book, or was fairly brief, but other essays I wrote sometimes required more space than PMLA would allow under a new policy that imposed a 9,000-word limit (it used to be 12,500). For my best work, I thought, I needed more space. Both my earlier essays had run longer than that. I could understand why the policy was adopted, but it did indeed cramp my style.

When I finally submitted a fourth article just a few years ago, I did so with misgivings. It wasn't the anonymous-submission policy that bothered me: my second essay was the first one accepted by the journal under that policy, which I still approve of; even so I always signed my reader's reports. Nor did the limit on length disturb me this time, though I would have been grateful for additional space. What worried me was my perception that the kinds of writing I liked to do were no longer in favor at PMLA. If "authors of high-quality manuscripts are no longer submitting their work to PMLA," as you speculated in the January 2001 issue (12), it's because some high-quality work may not please a new breed of advisory readers. For me, the increasing pervasiveness of new-historicist or theoretical or postcolonial or gender preoccupations made it seem less likely that formal-I prefer to say literaryanalysis (not blind to history, the history of forms among others, nor entirely innocent of theoretical implications) could make it into the pages of PMLA. And I may have been right, about my own case at least: my article, worked over for years, was rejected outright, not recommended for revision and resubmission; the reasons given convinced me only that the readers and I held different views about literature and criticism.

Whatever my regrets about what I judge to be the direction the journal has taken, I value it still for the news it provides of professional activities, the advertisements it runs, and the addresses I need, as well as for bonanzas like the special millennial issue or some of the issues on special topics and for the occasional memorable articles it publishes, solicited or unsolicited, by brilliant young writers (i.e., under 75); and none of my strictures is likely to make me forget or undervalue the generous and gracious treatment I've received, on balance, from the MLA and PMLA. But it can hardly be doubted, as several letters suggest, that PMLA has changed since the days when articles like mine were welcome. In a number of ways it has changed for the better. It is receptive to many more kinds of important scholarship and criticism than would have been publishable in those old days, and it is less indulgent to some tedious kinds of traditional dryasdust scholarship. But it is sad to see that it long ago renounced its claim to print only articles "that are of significant interest to the entire membership of the Association" (even though one of my own essays was hanged from that yardarm), and many scholars of my generation and later evidently suspect that the journal's advisory readers and editors will be much less sympathetic to essays that try, in Auden's words, to figure out how, in all its complexity, some "verbal contraption" works than to pieces that discourse, usually at a far remove from any particular verbal text, about empowerment, hegemony, colonialism, and globalization-important and fascinating subjects, without a doubt, but not the whole story of literature and certainly not what we ought mainly to be teaching in most literature classrooms.

\section{George T. Wright \\ University of Minnesota Twin Cities}

\section{Rigoberta Menchú}

\section{TO THE EDITOR:}

When I published Rigoberta Menchú and the Story of All Poor Guatemalans (1999), I wanted to encourage debate over representation in Latin American studies. Instead, I brought down an avalanche of ad hominem attacks, on the Nobel laureate for being a liar and on myself for casting doubt on her 1982 life story. 